\section{Yessotoxin detection in bivalve molluscs: A case study from coastal mussel farms (Sardinia, Italy)}

\author{
Alessandro Graziano Mudadu, \\ Giuseppa Lorenzoni, Anna Maria \\ Bazzoni, Riccardo Bazzardi, Giuseppe \\ Tedde, Igor Arras, Giovanna Sanna, \\ Cinzia Santucciu, Edoardo Marongiu, \\ Sebastiano Virgilio \\ Veterinary Public Health Institute of \\ Sardinia, Sassari, Italy
}

\begin{abstract}
This work reports the first communication relating to the presence of yessotoxins in Mytilus galloprovincialis from coastal mussel farms (Sardinia, western Mediterranean) detected during 2008 and 2013 through a monitoring programme. The paper emphasizes how the changes both in yessotoxin permitted limits and used methods, established by legislation, have influenced the interpretation of the obtained results. Consequently, the samples that resulted negative during 2008 would have been positive until August 2013 and negative from September 2013 up to now, and the samples that were positive in 2013 would have been positive in 2008 and negative nowadays, according to Regulation currently in force. Regular monitoring of biotoxins demonstrated that, although yessotoxins have been rarely present in the past in Sardinia, they may cause toxicity in shellfish. So, it's important to keep up on legislation's changing and laboratory methods.
\end{abstract}

\section{Introduction}

Yessotoxins (YTXs) are sulphated polyethers belonging to lipophilic phycotoxins family. They were first isolated in Japan in 1986 and afterward, production of YTXs has been demonstrated worldwide (Tubaro et al., 2010). In particular, in Italy the presence of YTXs in mussel was reported for the first time in hepatopancreas of mussels breeded in northern Adriatic Sea (Ciminiello et al., 1997). Potentially YTX producers are the dinoflagellates Protoceratium reticulatum (Claparède \& Lachmann) Bütschli, Lingulodinium polyedra (F. Stein) J.D. Dodge and Gonyaulax spinifera (Claparède \& Lachmann) Diesing.
The toxins can be accumulated by filtering within the edible bivalve molluscs, like mussels, scallops, and clams; this permits their entry into the food chain. YTXs were initially included in the Diarrhetic Shellfish Poisoning (DSP) toxin group due to their occurrence with okadaic acid (OA) and other lipophilic toxins, but it was demonstrated that they have a different mechanism of action and not produce diarrheal neither in humans nor in mice (Satake et al., 1997). For these reasons, nowadays they are considered in different groups (Alfonso et al., 2016) and are independently regulated (European Commission, EC 2004; 2013). The toxicological information for YTXs is limited and includes mainly studies on their acute toxicity in mice (Rodrìguez et al., 2015), even because no human cases of intoxication have been reported to date. Related YTX symptoms and toxicity effects after oral assumption are rather unknown in humans, so consumption of YTX-contaminated shellfish still remains an unidentified health risk (Tubaro et al., 2010). In contrast, mice showed discoordination described by jumping and restlessness, due to cerebellar cortical alterations as a result of damaged motor function (Wolf et al., 1996).

The Regulation EC No 853/2004 established the maximum levels of some marine biotoxins in molluses for human consumption. Successively, the Regulation EC No 15/2011 of 10 January 2011 amended the previous Regulation EC No 2074/2005 as regards recognised testing methods for detecting marine biotoxins in live bivalve molluses and established that Liquid Chromatography-Mass Spectrometry (LCMS/MS) method will be used as the reference method instead of mouse bioassay (MBA). However, to allow Member States to adapt their methods to the chemical one, the MBA could be used until 31 December 2014. Furthermore, Commission Regulation No 786/2013 of 16 August 2013 amending Annex III to Regulation EC No $853 / 2004$, as regards the permitted limits of YTXs in live bivalve molluscs, established the increasing from 1 to $3.75 \mathrm{mg}$ eq YTX/Kg e.p.. The selective procedure for detection of YTXs defined from Spanish agency for food security (Agencia Española de Seguridad Alimentaria y Nutrición, AESAN) in the Annex 2009, didn't allow to evaluate this amount, so the extraction was performed with the non-selective method for lipophilic toxins. The mice death was followed by LC-MS/MS method confirmation, that identifies and quantifies the toxins.

Following European legislation, toxicity analyses were carry out until 31 December 2014 by means of the MBA, as
Correspondence: Alessandro Graziano Mudadu, Veterinary Public Health Institute of Sardinia, Via Duca degli Abruzzi 8, 07100 Sassari (SS), Italy.

Tel.: +39.0792892348 - Fax: +39.0792892324.

E-mail: decambis@yahoo.it

Key words: Lipophilic toxins, Mediterranean, Mussels, Shellfish farms, YTXs.

Contributions: the authors contributed equally.

Conflict of interest: the authors declare no potential conflict of interest.

Received for publication: 23 August 2017

Revision received: 30 October 2017.

Accepted for publication: 30 October 2017.

This work is licensed under a Creative Commons Attribution-NonCommercial 4.0 International License (CC BY-NC 4.0).

(C) Copyright A.G. Mudadu et al., 2017

Licensee PAGEPress, Italy

Italian Journal of Food Safety 2017; 6:7015

doi:10.4081/ijfs.2017.7015

indicated in the Official Bulletin of Italian Republic (Gazzetta Ufficiale della Repubblica Italiana, G.U.R.I.) n. 165, 16 July 2002. Between 2011 and 2014, samples which provoked mice death within the 24 hours were subsequently confirmed by LC-MS/MS. From 2015 the MBA has been replaced by the official LC-MS/MS protocol.

This study shows the first evidence relating to the presence of YTXs in shellfish from Sardinia (Italy, western Mediterranean), occurred during 2008 and 2013. Furthermore, it also emphasizes how the changes established by legislations, may have influenced the interpretation of the obtained results, both in YTX permitted limits and in used methods.

\section{Materials and Methods}

Shellfish were collected fortnightly (Mytilus galloprovincialis, Tapes decussatus, Crassostea gigas, Ostrea edulis, Veneroidae) in 2008 and in 2013 in breeding areas located along coastline of Sardinia (Figure 1), where a plan of periodic monitoring and of sanitary control for the production and marketing of molluscs has been in force since 1988. A total of 834 bivalve mollusc samples were analysed in 2008 and a total of 892 during 2013.

For the research of lipophilic toxins using the MBA, lipid extract preparation involved $100 \mathrm{~g}$ of mussels mixed with 300 
$\mathrm{ml}$ of acetone (VWR CHEMICALS, Fontenay-sous-Bois, France) in UltraTurrax (T25 basic IKA_WERKE), filtered and re-extracted with $200 \mathrm{ml}$ of acetone. The acetone supernatant was mixed and evaporated with a rotavapor (Büchi Rotavapor R-200), yielding a residue which was recovered with $30 \mathrm{ml}$ of dichloromethane (SIGMA-ALDRICH, St Luis USA) and $60 \mathrm{ml}$ of methanol (VWR PROLABO, Fontenay-sous-Bois, France) $(60 \% \mathrm{v} / \mathrm{v})$ and subjected to partition by the separating funnel. The methanol phase was stored and the dichloromethane phase was re-extracted twice with $60 \mathrm{~mL}$ of methanol. For both extracts, solvent was evaporated and the resultant residue suspended in aqueous solution of $1 \%$ Tween 60 (SIGMAALDRICH, St Luis USA). For the investigation of OA-toxin group, Pectenotoxin group (PTXs) and Azaspiracid group

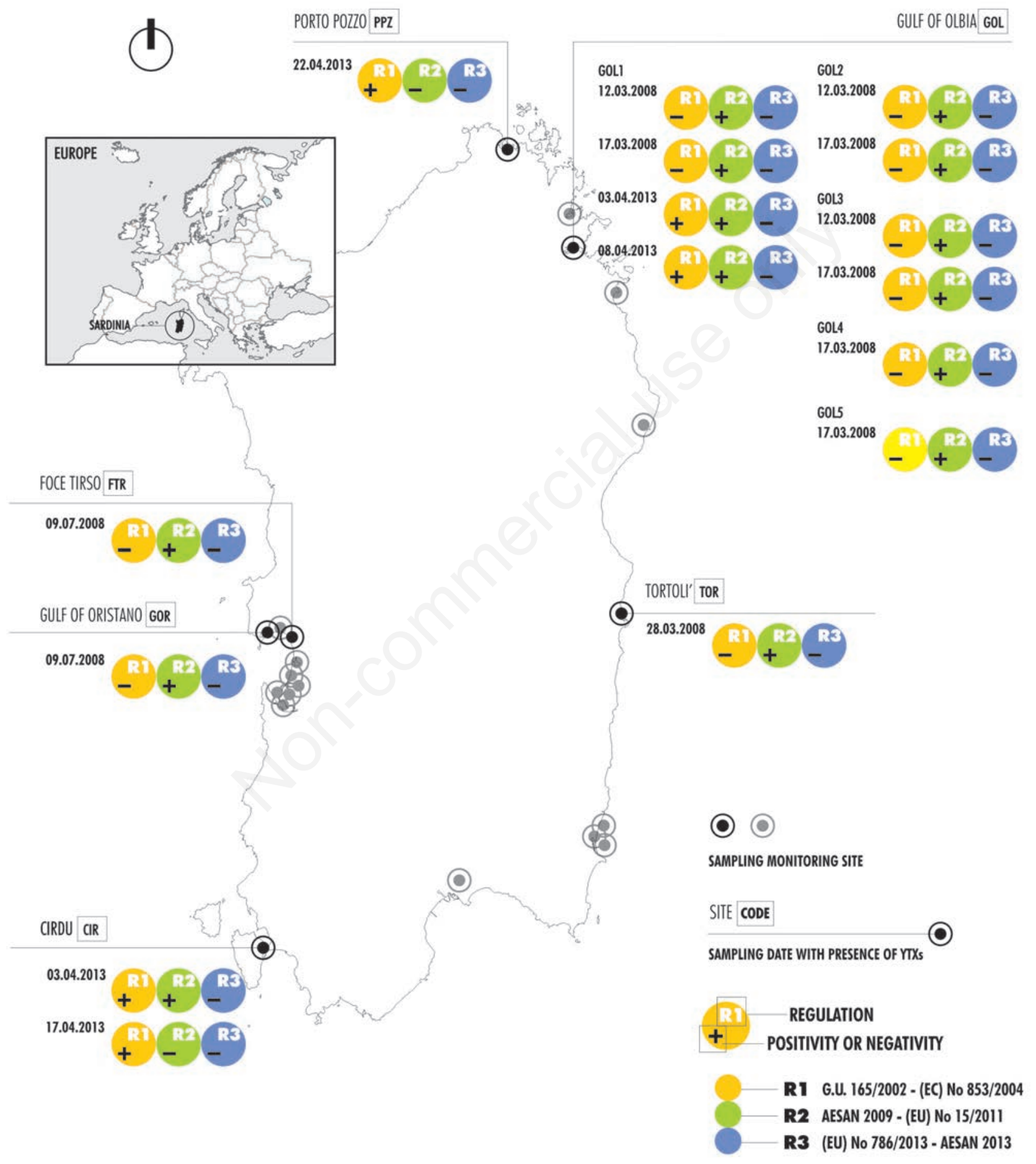

Figure 1. Monitoring network and changes of result interpretation based on Regulation update from 2008 to 2013 . G.U. Gazzetta Ufficiale; EC: European Commission; EU: European Union; AESAN: Agencia Española de Seguridad Alimentaria y Nutrición. 
(AZAs), one ml of dichloromethane extract was injected intraperitonelly into albino mice Swiss strain weighing between $19 \mathrm{~g}$ and $21 \mathrm{~g}$. The death of 2 out of 3 injected mice, within a 24 hours observation period, constituted a positive result. For the specific determination of YTXs, the methanolic extract was injected in mice. The death of 2 out of 3 mice, within a 5 hours (with a 6 hours observation period), constituted a positive result (G.U.R.I. 165/2002).

In the use of Harmonised Standard Operating Procedure by MBA (AESAN, 2009), the death of 2 out of 3 injected mice within 6 hours observation, with a YTX specific symptomatology, constituted a positive result. The positive samples were subjected to LC-MS/MS method. It was based on the extraction of OA toxin group, PTXs, AZAs and YTXs by homogenized mussel tissues with methanol $90 \%$. Extract was then filtered and directly analyzed by LCMS/MS (AB SCIEX QTRAP 4500) (AESAN, 2015). To determine the total content of lipophilic toxins, an alkaline hydrolysis was necessary. After hydrolysis, extract was filtered and analysed by LCMS/MS. Chromatographic separation was performed by gradient elution.

\section{Results and Discussion}

During 2008, symptoms attributable YTXs were seen in mice injected with extract of Mytilus galloprovincialis (Lamarck) from the eastern and western Sardinian coasts, in particular in March at Gulf of Olbia (in five stations, named GOL1 to GOL5) and Tortolì (TOR), and in July at Gulf of Oristano (GOR) and Foce del Tirso (FTR). The mice died between five and six hours. It declared no shellfish intoxication, in according to regulations in force that defined the death time within five hours of observation. Furthermore, on other occasions, in the same areas, YTXs caused the mice's death in a longer time (between six and eight hours).

During April 2013, YTXs were again detected in mussels, once more in M. galloprovincialis (Table 1). Based on the applicable regulation (Figure 1), which established the death time within six hours, the biological test detected the presence of YTXs in five samples, two at GOL1, two at Cirdu (CIR) and one at Porto Pozzo (PPZ). The following LC-MS/MS-based approach confirmed the toxin presence over the legal limit (1 mg YTX/Kg e. p.) only in three shellfish samples that tested positive to the MBA, two from GOL1 and one from CIR (Table 1). The YTX contamination levels in shellfish from both studied areas were quite low (maximum $1.53 \mathrm{mg} \mathrm{YTX} / \mathrm{Kg}$ e.p. in GOL1) (Table 1) and subsequently decreased gradually in about two weeks.

Since 2013 to now in no one shellfish samples, all analysed by LC/MS/MS, YTX evidence was found.

Both on 2008 and 2013 the presence of YTXs was not linked to the occurrence of harmful microalgae potentially producing YTX and no other lipophilic toxins currently legislated in the Europe was isolated at the same time.

The lack of chemical, physical and environmental data related to YTXs did not allow us to identify a seasonal trend, anyway as in 2008 as in 2013 all positive samples were observed between late March and July. This is in contrasts with general trend reported in several areas (e.g. French coastline, Amzil et al., 2008; north-central Adriatic Sea, Bacchiocchi et al., 2015) where it seems that autumn-winter is the most critical period of the year for YTX contamination.

In the last fifteen years, legislation about YTXs has changed several times both in reference methods and in the regulatory limits. New regulations (EC No 15/2011) have imposed to replace the MBA with the LC-MS/MS method. Moreover, on basis of provisional data which indicate that YTXs pose a modest risk for European population,

Table 1. Mice death time and amount of yessotoxins found in 2013 by LC-MS/MS-based approach.

\begin{tabular}{lcccc} 
Site & Site Code & Data & $\begin{array}{c}\text { Mice death time } \\
\text { (h) }\end{array}$ & $\begin{array}{c}\text { YlXs } \\
\text { (mg YIX/Kg e. p.) }\end{array}$ \\
Gulf of Olbia & GOL1 & $03 / 04 / 2013$ & $<5$ & 1.53 \\
Gulf of Olbia & GOL1 & $08 / 04 / 2013$ & $<3$ & 1.03 \\
\hline Cirdu & CIR & $03 / 04 / 2013$ & $<3$ & 1.37 \\
Cirdu & CIR & $17 / 04 / 2013$ & $<3$ & $0.97^{*}$ \\
\hline Porto Pozzo & PPZ & $22 / 04 / 2013$ & $<4$ & $0.77^{*}$ \\
\hline
\end{tabular}

*Toxin presence without the overcoming of the legal limit of $1 \mathrm{mg}$ YTX/Kg e. p. (EC No 853/2004, AESAN 2009). GOL1: Station 1 of Gulf of Olbia. maximum level has been amended from 1 to $3.75 \mathrm{mg} \mathrm{YTX/Kg} \mathrm{e.} \mathrm{p.,} \mathrm{and} \mathrm{it} \mathrm{could} \mathrm{be}$ still reassessed if were new scientific evidence available. If we tried to re-evaluate our data following the legislation evolution: i) the samples that resulted negative during 2008 would have been positive in 2013 and negative again from September 2013 up to now; ii) the samples that resulted positive in April 2013 would have been negative both in 2008 and nowadays, with the legislation currently in force (Figure 1). This shows that there is still considerable uncertainty about threat for humans who have generated a series of legislative changes in recent decades, but also a constant attention to what derives from different European studies and researches.

\section{Conclusions}

In recent years, various scientists have published about the YTX detection and quantization in shellfish samples (Alvez-de Souza et al., 2013; Li et al., 2012; Paz et al., 2013). This highlights the widespread distribution of YTXs along coasts and their increasing occurrence in edible bivalve molluscs. Our study is placed in the context to make data available for the existing database to build up information for the management of the risk of these toxins in shellfish.

\section{References}

AESAN, 2009. EU-harmonised standard operating procedure for detection of lipophilic toxins by mouse bioassay. European Union Reference Laboratory for Marine Biotoxins, Agencia Española de Consumo, Seguridad Alimentaria y Nutrición, Vigo, Spain.

AESAN, 2015. EU-harmonised standard operating procedure for determination of lipophilic marine biotoxins in molluscs by LCMS/MS. Version 5. European Union Reference Laboratory for Marine Biotoxins, Agencia Española de Consumo, Seguridad Alimentaria y Nutrición, Vigo, Spain.

Alfonso A, Vieytes MR, Botana LM, 2016. Yessotoxin, a promising therapeutic tool. Mar Drugs 14:30.

Alves-de-Souza C, Varela D, Contreras C, de La Iglesia P, Fernandez P, Hipp B, Hernandez C, Riobò $\mathrm{P}$, Reguera $\mathrm{B}$, Franco JM, Diogene J, Garcia C, Lagos N, 2014. Seasonal variability of Dinophysis spp. and Protoceratium reticulatum associated tolipophilic 
shellfish toxins in a strongly stratified Chilean fjord. Deep-Sea Res 101:15262.

Amzil Z, Sibat M, Royer F, Savar V, 2008. First report on azaspiracid and yessotoxin groups detection in French shellfish. Toxicon 52:39-48.

Bacchiocchi S, Siracusa M, Ruzzi A, Gorbi $\mathrm{S}$, Ercolessi M, Cosentino MA, Ammazzalorso P, Orletti R, 2015. Twoyear study of lipophilic marine toxin profile in mussels of the North-central Adriatic Sea: First report of azaspiracids in Mediterranean seafood. Toxicon 108:115-25.

Ciminiello P, Fattorusso E, Forino M, Magno S, Poletti R, Yasumato T, 1997. Yessotoxin in mussel of the northern Adriatic Sea. Toxicon 35:177-83.

European Commission, 2004. Regulation of the European Parliament and of the Council of 29 April 2004 laying down specific hygiene rules for on the hygiene of foodstuffs, $853 / 2004 / \mathrm{CE}$. In: Official Journal, L 139/55, 30/04/2004.

European Commission, 2005. Regulation of the European Parliament and of the Council of 5 December 2005 laying down implementing measures for certain products under Regulation (EC) No $853 / 2004$ of the European Parliament and of the Council and for the organisation of official controls under
Regulation (EC) No 854/2004 of the European Parliament and of the Council and Regulation (EC) No 882/2004 of the European Parliament and of the Council, derogating from Regulation (EC) No $852 / 2004$ of the European Parliament and of the Council and amending Regulations (EC) No $853 / 2004$ and (EC) No 854/2004. In: Official Journal, L 338, 22/12/2005.

European Commission, 2011. Commission Regulation (EU) No 15/2011 of 10 January 2011 amending Regulation (EC) No 2074/2005 as regards recognised testing methods for detecting marine biotoxins in live bivalve molluscs. In: Official Journal, L 6/3, 11/01/2011.

European Commission, 2013. Commission Regulation (EU) No 786/2013 of 16 August 2013 amending Annex III to Regulation (EC) No 853/2004 of the European Parliament and of the Council as regards the permitted limits of yessotoxins in live bivalve molluscs. In: Official Journal, L 220/14, 17/08/2013.

Gazzetta Ufficiale della Repubblica Italiana, 2002. Regulation of 16 May 2002 as regards the maximum levels and analytic methods for algal biotoxins in live bivalve molluscs, echinoderms, tunicates and marine gasteropods (in Italian). Serie Generale, 165,
16/07/2002, p. 15

Li A, Ma J, Cao J, McCarron P, 2012. Toxins in mussels (Mytilus galloprovincialis) associated with diarrhetic shellfish poisoning episodes in China. Toxicon 60:420-5.

Paz B, Blanco J, Franco JM, 2013. Yessotoxins production during the culture of Protoceratium reticulatum strains isolated from Galician Rias Baixas (NW Spain). Harmful Algae 2122:13-9.

Rodríguez LP, González V, Martínez A, Paz B, Lago J, Cordeiro V, Blanco L, Vieites JM, Cabado A. G, 2015. Occurrence of lipophilic marine toxins in shellfish from Galicia (NW of Spain) and synergies among them. Mar Drugs 13:166687.

Satake M, Tubaro A, Lee JS, Yasumoto T, 1997. Two new analogs of yessotoxin, homoyessotoxin and 45-hydroxyhomoyessotoxin, isolated from mussels of the Adriatic Sea. Nat Toxins 5:107-10.

Tubaro A, Dell'Ovo V, Sosa S, Florio C, 2010. Yessotoxins: A toxicological overview. Toxicon 56:163-72.

Wolf LW, LaRegina MC, Tolbert DL, 1996. A behavioral study of the development of hereditary cerebellar ataxia in the shaker rat mutant. Behav Brain Res 75:67-81. 